\title{
The seasonal diet of Aequidens tetramerus (Cichlidae) in a small forest stream in the Machado River basin, Rondônia, Brazil
}

\author{
Igor David da $\operatorname{COSTA}^{1 *}$, Maiza Oliveira SOARES ${ }^{1}$ \\ 1 Universidade Federal de Rondônia, Campus Presidente Médici, Departamento de Engenharia de Pesca, Laboratório de Ciências Ambientais. Rua da Paz, 4376 , Bairro Lino Alves \\ Teixeira, CEP: 76.916-000, Presidente Médici, Rondônia, Brasil. \\ Corresponding author: igorbiologia@yahoo.com.br
}

\begin{abstract}
Trophic relationships in fish communities are affected by the availability of resources, which in turn is affected by spatial and temporal variations throughout the year. The aims of this study were to characterize the diet of $A$. tetramerus in a streamlet in the north of Brazil and compare its composition in different hydrological seasons (wet and dry seasons). Collections were performed every two months from October 2011 to September 2012 with the aid of seine nets, hand net and fishing traps in the streamlet located in the Machado River drainage basin in the Rondônia state. Most of the specimens collected were quite small $(<40 \mathrm{~mm})$ and had empty stomachs. Our results showed that $A$. tetramerus feeds on a wide variety of items of plant origin, such as algae, seeds and leaves, as well as items of animal origin, including bryozoans, crustaceans, fish scales, terrestrial insects and detritus. The data also indicated higher consumption of aquatic insects than other food items, suggesting a primarily insect-based diet. Items of plant and allochthonous origin were consumed more in the wet season than in the dry season, but there were no seasonal differences in the consumption of animal and autochthonous items.
\end{abstract}

KEYWORDS: Fish, Perciformes, Amazon, feeding habits, ornamental fish.

\section{Dieta sazonal de Aequidens tetramerus (Cichlidae) em um igarapé da bacia do rio Machado, Rondônia, Brasil}

\section{RESUMO}

Relações tróficas das comunidades de peixes são afetadas por variaçôes espaciais e temporais, que alteraram a disponibilidade de recursos ao longo do ano. Os objetivos deste estudo foram caracterizar a dieta de $A$. tetramerus no igarapé estudado, bem como comparar se a composição dos itens da dieta desta espécie dependem da estaçáo hidrológica (período chuvoso e seco). As coletas foram realizadas bimestralmente, de Outubro de 2011 a Setembro de 2012, com auxílio de picaré, puçá e covos em um igarapé localizado na bacia do rio Machado no estado de Rondônia. A maioria dos espécimes eram pequenos (< $40 \mathrm{~mm}$ ) e tinham estômago vazio. Observou-se que $A$. tetramerus se alimenta de uma grande variedade de itens de origem vegetal, como algas, sementes e folhas; e de itens de origem animal como: briozoários, crustáceos, escamas, insetos terrestres e detritos. Constatou-se que há maior consumo de insetos aquáticos, o que sugere uma dieta insetívora. Itens de origem vegetal e alóctones foram mais consumidos na estação chuvosa do que na estação seca. Não houve diferença na composição da dieta dos peixes entre as estaçóes de seca e chuva.

PALAVRAS-CHAVE: Peixe, Perciformes, Amazônia, hábitos alimentares, peixe ornamental. 


\section{INTRODUCTION}

One approach for evaluating interactive processes in aquatic communities that yields consistent results is to investigate the diet of fishes (Reis and Santos 2014), whose feeding habits can be influenced by environmental conditions, the biological characteristics of the species (e.g., development of individuals) (Abelha et al. 2001) and spatial and temporal variations (Ximenes et al. 2011).

Small forest streams (regionally known as igarapés) are watercourses that are poor in nutrients and have low primary production (Mendonça et al. 2008). Food chains in these watercourses therefore depend on allochthonous matter from nearby forests (Abilhoa 2009). A further characteristic of these streams is that the water level is subject to frequent, rapid flood pulses (Carvalho et al. 2013). After the onset of heavy rains, the water level rises, often overflowing and reaching the surrounding valley (Espírito-Santo et al. 2009).

Trophic relationships in fish communities are affected by spatial and temporal variations (Ferreira et al. 2014), as these affect the qualitative and quantitative availability of resources throughout the year (Ximenes et al. 2011). Several studies have shown that fish select food resources based on their availability in the environment (e.g., Gonçalves et al. 2013; Nogueira and Costa 2014).

Trophic ecology studies have demonstrated that most teleost fishes exhibit considerable feeding versatility (Abelha et al. 2001). However, South American cichlids appear not to have a great variety of feeding tactics; some of these tactics (e.g., plowing sandy and rocky substrate and preying on invertebrates in macrophytes and the water column) may be related to certain types of microhabitat occupancy (Sampaio and Goulart 2011), similarly to the tactics of Aequidens tetramerus, the species studied here.

Aequidens tetramerus (Heckel, 1840), also known as "saddle cichlid", is a native neotropical fish (Moreira and Zuanon 2002) of ornamental importance (Regulatory Directive 001/2012-MPA/MMA) that has a small body and short snout (Montaña and Winemiller 2013) and consumes mainly food of animal origin (Moreira and Zuanon 2002).

According to Espírito-Santo et al. (2009), fish assemblages in small streamlets and the physical characteristics of these streamlets vary with season. Seasonal wind and rainfall variations can be expected to result in allochthonous matter entering streams in different patterns (Angermeier and Karr 1983). The aims of the present study were to characterize the diet of $A$. tetramerus in a streamlet in the north of Brazil and compare its composition in two different hydrological seasons (wet and dry). Specifically, we analyzed the differences in length classes, repletion degree and type and origin of food items between dry and wet seasons.

\section{MATERIALS AND METHODS}

\section{Study Area}

The streamlet studied here is known as the do Nove streamlet (61'51'24"S; $\left.11^{\circ} 15^{\prime} 31^{\prime \prime} \mathrm{W}\right)$ and is located in the Machado River drainage basin in the east of the state of Rondônia (Figure 1). The temperature varies between 19 and $33{ }^{\circ} \mathrm{C}$, and annual precipitation is about $2,500 \mathrm{~mm}$ (Krusche et al. 2005). The dry season extends from April to September, and the wet season from October to March (SEDAM 2010). The streamlet is a lower (first) order one, with a sandy substratum, pastures in the adjacent matrix and a small amount of riparian vegetation consisting of grass and small aquatic plants. In the dry season the mean depth was $100 \pm 0.1 \mathrm{~cm}$, mean width $60 \pm 0.1 \mathrm{~cm}$, mean water speed $0.1 \pm 0.0 \mathrm{~m} \mathrm{~s}^{-1}$ and mean flow $1.2 \pm 0.1 \mathrm{~m}^{3} \mathrm{~s}^{-1}$, while in the wet season the corresponding figures were $150 \pm 0.1 \mathrm{~cm}, 120$ $\pm 0.5 \mathrm{~cm}, 0.2 \pm 0.0 \mathrm{~m} \mathrm{~s}^{-1}$ and $1.3 \pm 0.2 \mathrm{~m}^{3} \mathrm{~s}^{-1}$.

\section{Sampling and data analysis}

Samples were collected every two months from October 2011 to September 2012 (totaling three samples for each season) along a $50 \mathrm{~m}$ stretch of the streamlet. Seine nets (picarés) measuring $2.0 \times 1.20 \mathrm{~m}$ with a mesh size of $2 \mathrm{~mm}$ and a hand net (puçá) with a $0.46 \times 0.33$ m opening and a mesh size of $2 \mathrm{~mm}$ were used simultaneously along the whole stretch for one hour. In addition, ten fishing traps (covos) made with 2 L PET bottles containing ground corn bait were placed 20 $\mathrm{m}$ upstream from the area where active collections were made. The bottles were placed $2 \mathrm{~m}$ apart along the whole stretch, with the opening facing downstream. They were left for 24 $\mathrm{h}$ and checked every $4 \mathrm{~h}$. Before sampling, each end of the $50 \mathrm{~m}$ sampling site was blocked with small-mesh nets $(5 \mathrm{~mm}$ between opposite knots) to prevent fishes from escaping. Each specimen collected was fixed in $10 \%$ formalin and preserved in $70 \%$ ethanol.

The standard length (SL) of each specimen was measured to identify length classes (LCs). Stomach contents were then stored in 70\% alcohol, and food items were identified down to the lowest taxonomic level with the aid of Hamada and Ferreira-Keppler (2012) and Hamada et al. (2014) using a stereoscopic microscope. Repletion degree (RD) was determined according to the scale proposed by Hahn et al. (1999) and was coded as follows: 0 (empty), 1 (volume < $25 \%), 2(25 \%-75 \%)$ and $3(75 \%-100 \%)$. The frequency of occurrence $(\mathrm{F} i \%)$ and volume $(\mathrm{V} i \%)$ methods were used to analyze stomach contents (Hyslop 1980). The volume of each item was obtained using a petri dish with a millimeter scale and was then converted into milliliters (Hellawell and Abel 1971). These data were combined in an alimentary index (IA $i$ ) proposed by Kawakami and Vazzoler (1980). The index is given by the equation $\mathrm{IA} i=(\mathrm{F} i * \mathrm{~V} i) / \Sigma \mathrm{F} i * \mathrm{~V} i)^{*} 100$, where 


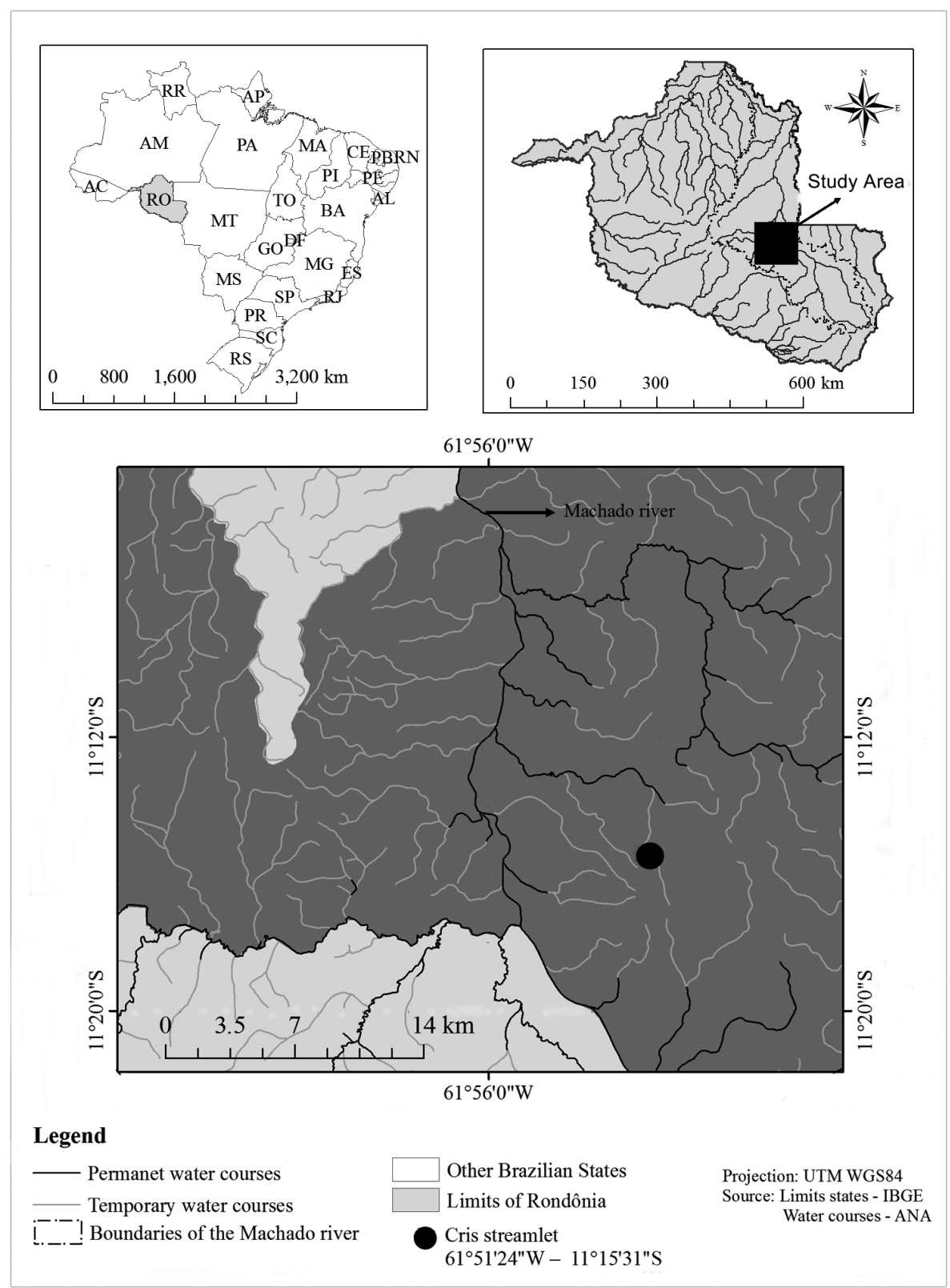

Figure 1. Map of the Machado River basin with the study sites indicated (black circle).

$i=1.2, \ldots \mathrm{n}$ food items; $\mathrm{F} i=$ frequency of occurrence of a given food item; and $\mathrm{V} i=$ volume of a given food item. Food items were grouped according to type (animal or plant) and origin (autochthonous or allochthonous).

The Kolmogorov-Smirnov test of normality and Levene's test of homoscedasticity were used to determine whether parametric ANOVA or the non-parametric Kruskal-Wallis test should be used to test for differences between LC (length classes) and RD (repletion degree) (Zar 1999). Chi squared tests $(\chi 2)$ were applied to data that had a normal distribution and exhibited homoscedasticity to detect seasonal differences (dry versus wet season) in absolute frequency of LC, RD and type and origin of food items (Zar 1999).

Non-metric multidimensional scaling analysis (nMDS) was used to examine temporal variation in diet using the total volume values of each item. The analyses of variance (ANOVA and Kruskal-Wallis) and $\chi 2$ tests were performed with Statistica 7.1 (StatSoft 2005). NMDS was carried out using the PAST package (version 2.1.7) (Hammer et al. 2001). Results were considered significant when $p \leq 0.05$. 


\section{RESULTS}

A total of 59 specimens were analyzed; 25 were collected in the wet season and 34 in the dry season. Most of the specimens were longer than $10 \mathrm{~mm}$, and the length class with the greatest absolute frequency was LC $10-20 \mathrm{~mm}(\mathrm{n}=22)$, followed by LC $21-30 \mathrm{~mm}(\mathrm{n}=19)$, LC $31-40 \mathrm{~mm}(\mathrm{n}=9)$ and LC $41-50 \mathrm{~mm}(\mathrm{n}=5)$ (Figure 2). No significant differences were found between the length classes analyzed (ANOVA, F = 4.54; $\mathrm{p}=0.02 ; \mathrm{df}=1)$. Only the absolute frequency of smaller individuals $(10-20 \mathrm{~mm})$ differed significantly in the dry season $(n=19)$ and wet season $(n=3)(\chi 2=11.6 ; p<0.05)$.

No significant differences were found between the values of repletion degree analyzed (ANOVA, F = 2.36; $\mathrm{p}=0.20$; $\mathrm{df}=1$ ) or between these values for the two seasons (Table 1 ).

Aequidens tetramerus ingested a wide variety of food items, including material of plant origin, such as algae, seeds and leaves; material of animal origin, such as bryozoans, crustaceans, scales and terrestrial and aquatic insects at different stages of the life cycle; and undefined matter (detritus/mud). Fragments of aquatic insects were the most consumed item in both seasons (dry, IA $i=52.76$; wet, IA $i=$ 38.47 ), followed by trichopterans (IA $i=18.70)$, seeds (IA $i=$ $12.68)$ and plant matter $(\mathrm{IA} i=12.16)$ in the wet season and detritus $(\mathrm{IA} i=26.16)$ in the dry season (Table 2$)$.

Items of plant origin were consumed more in the wet season than in the dry season $(\chi 2=19.0, \mathrm{p}<0.05)$. There were no significant differences between seasons for food items of animal origin $(\chi 2=3.0, p>0.05)$. While allochthonous items were consumed more in the wet season than in the dry season $(\chi 2=16.0, \mathrm{p}<0.05)$, there were no significant differences between seasons for autochthonous items $(\chi 2=3.4, \mathrm{p}>0.05)$. Food items of animal origin were more abundant than items of plant origin in the wet season $(\chi 2=25.0, \mathrm{p}<0.05)$ and dry season $(\chi 2=92.0, \mathrm{p}<0.05)$. Autochthonous items were consumed more than allochthonous items in both seasons (wet: $\chi^{2}=17.6, \mathrm{p}<0.05$; dry: $\chi^{2}=81.0, \mathrm{p}<0.05$ ).

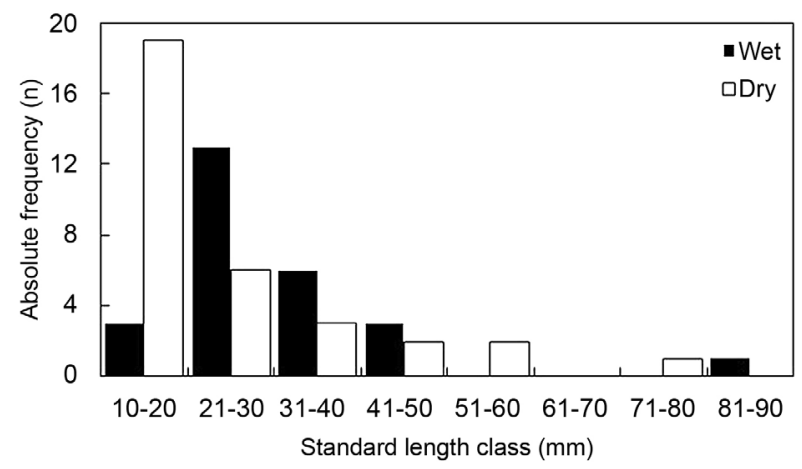

Figure 2. Absolute frequency (n) of $A$. tetramerus specimens from the do Nove streamlet in each standard length (SL) class.
nMDS analysis based on the total volume of each item of animal (stress $=0.47)$, plant (stress $=0.47)$, autochthonous (stress $=0.55)$ and allochthonous origin (stress $=0.46$ ) in each season failed to show any separation on axis 1 and 2 retained for interpretation (Figure 3).

Table 1. Absolute frequency of $A$. tetramerus specimens from the do Nove streamlet for each stomach repletion degree class. Repletion degree 0 (RD 0 $=$ empty), repletion degree $1(\mathrm{RD} 1=<25 \%)$, repletion degree $2(\mathrm{RD} 2=$ $25 \%-75 \%$ ) and repletion degree 3 (RD $3=75 \%-100 \%) ; x 2$ = values of the chi-square test; $p=$ significance.

\begin{tabular}{lcccc}
\hline $\begin{array}{l}\text { Repletion } \\
\text { degree }\end{array}$ & \multicolumn{2}{c}{ Absolute frequency } & \multirow{2}{*}{ X2 } & $p$ \\
\cline { 2 - 3 } & Wet season & Dry season & & \\
\hline RD 0 & 9 & 11 & 0.20 & 0.31 \\
RD 1 & 8 & 9 & 0.52 & 0.67 \\
RD 2 & 4 & 8 & 1.33 & 0.24 \\
RD 3 & 4 & 6 & 0.40 & 0.52 \\
\hline
\end{tabular}

Table 2. Percentage composition by volume (Vi), occurrence (Fi) and alimentary index (IAi) of each food item identified in the $\operatorname{diet}$ of $A$. tetramerus during the wet and dry seasons in the do Nove streamlet in the Machado River basin, Rondônia. Allochthonous items*; autochthonous items**.

\begin{tabular}{|c|c|c|c|c|c|c|}
\hline \multirow{2}{*}{ Food item } & \multicolumn{3}{|c|}{ Wet season } & \multicolumn{3}{|c|}{ Dry season } \\
\hline & Vi\% & $\mathrm{Fi} \%$ & $\mid A i$ & Vi\% & $\mathrm{Fi} \%$ & $\mathrm{IA} i$ \\
\hline \multicolumn{7}{|l|}{ Plant origin } \\
\hline Filamentous algae** & & & & 3.49 & 1.54 & 0.48 \\
\hline $\begin{array}{l}\text { Algae } \\
\text { (Bacillariophyceae) }^{* *}\end{array}$ & 0.04 & 2.38 & 0.01 & 0.28 & 3.08 & 0.08 \\
\hline Seeds* & 19.50 & 7.14 & 12.68 & 1.16 & 1.54 & 0.16 \\
\hline $\begin{array}{l}\text { Plant matter (leaves } \\
\text { and twigs)* }\end{array}$ & 11.21 & 11.90 & 12.16 & 2.37 & 3.08 & 0.66 \\
\hline \multicolumn{7}{|l|}{ Animal origin } \\
\hline Bryozoa** & 3.71 & 11.90 & 4.03 & 0.65 & 7.69 & 0.45 \\
\hline Diptera* & 0.00 & 0.00 & 0.00 & 4.77 & 7.69 & 3.30 \\
\hline Ceratopogonidae** & 2.32 & 7.14 & 1.51 & 2.35 & 7.69 & 1.63 \\
\hline Chironomidae** & 6.86 & 7.14 & 4.46 & 8.67 & 7.69 & 6.01 \\
\hline Coleoptera* & 8.43 & 4.76 & 3.66 & 1.40 & 1.54 & 0.19 \\
\hline Hymenoptera* & & & & 3.33 & 3.08 & 0.92 \\
\hline Lepidoptera* & & & & 0.42 & 1.54 & 0.06 \\
\hline Plecoptera** & 1.07 & 2.38 & 0.23 & & & \\
\hline Trichoptera** & 17.25 & 11.90 & 18.70 & 6.02 & 9.23 & 5.01 \\
\hline Cladocera** & 0.11 & 2.38 & 0.02 & 2.51 & 7.69 & 1.74 \\
\hline Copepoda** & & & & 0.93 & 1.54 & 0.13 \\
\hline $\begin{array}{l}\text { Fragments of aquatic } \\
\text { insects**}\end{array}$ & 22.18 & 19.05 & 38.47 & 29.28 & 20.00 & 52.76 \\
\hline Scales** & 3.82 & 9.52 & 3.31 & 0.60 & 4.62 & 0.25 \\
\hline \multicolumn{7}{|l|}{ Unidentified Material } \\
\hline Detritus/mud** & 3.50 & 2.38 & 0.76 & 26.95 & 10.77 & 26.16 \\
\hline
\end{tabular}



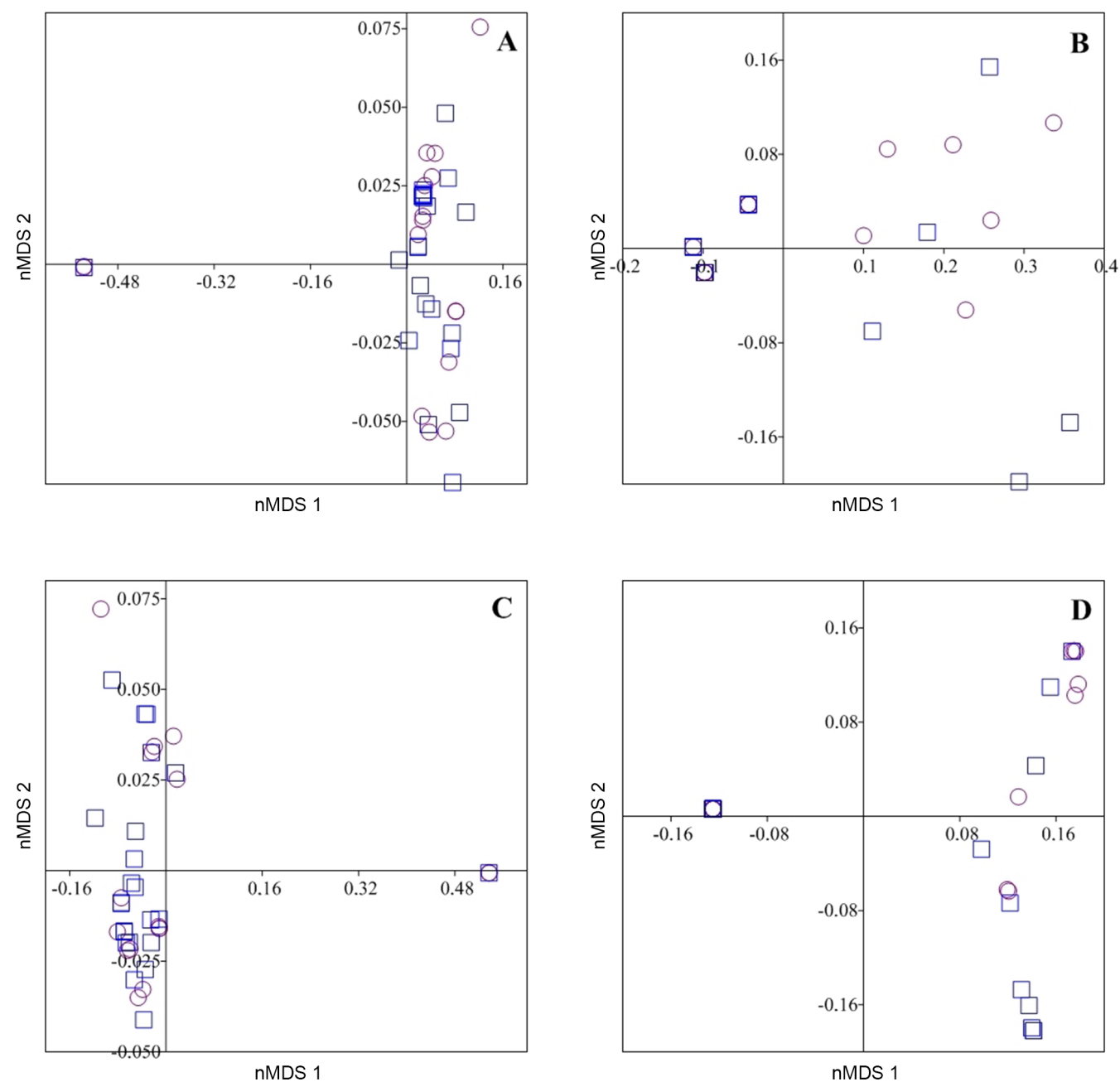

Figure 3. Non-metric multidimensional scaling analysis of volumetric data for animal (A), plant (B), autochthonous (C) and allochthonous (D) items in the diet of $A$. tetramerus from the do Nove streamlet during the dry season (square) and wet season (circle).

\section{DISCUSSION}

Streamlets in mainland forests are important components of the Amazon fluvial system as they shelter many fish species (Casatti et al. 2013), particularly small species with a total length of less than $100 \mathrm{~mm}$ (Bührnheim 2002). The family Cichlidae includes approximately 105 genera, with 1,300 species of freshwater and brackish water fish described, and is considered one of the largest families of fish although Kullander (2003) believes the number of species has probably been underestimated. It is also considered one of the most specious and common families in streamlets in the Amazon Forest (Mendonça et al. 2008; Casatti et al. 2013).

In contrast to our results, Soares (1979) found greater abundance of $A$. tetramerus in $\mathrm{LC}>40 \mathrm{~mm}$. This difference is probably related to the fact that the streams studied by
Soares were larger (higher order, with a mean width of 260 $\pm 29 \mathrm{~cm}$ ) than the streams in the present study. According to Bührnheim (2002), most of the fish species in mainland streams are small and use shallow habitats with large marginal areas as shelter against predators. Juveniles of Aequidens sp. measuring less than $30 \mathrm{~mm}$ in length tend to remain in groups in the middle of the vegetation in shallow waters under parental care (Goldstein 1973).

According to Benitez and Suárez (2009), hydrological differences, such as flow variability and the physical and chemical characteristics of the water, affect the population characteristics of the species. We infer that the lower abundance of small individuals in the rainy season can be explained by the greater dispersion of individuals to marginal environments, where there are rooted emergent macrophytes, and to the increase in channel depth, which provides a greater 
number of habitats and resources to be exploited, making the fish less susceptible to capture by our active fishing equipment.

A study by Soares (1979) carried out in a streamlet in the Brazilian state of Mato Grosso describes a high frequency of empty stomachs $(50 \%)$ for A. tetramerus. Although we found no differences between the seasons for repletion degree in our study, we observed a lower frequency of individuals with full stomachs than Soares. According to Moreira and Zuanon (2002), this indicates that the feeding strategy used by cichlids is based on constant foraging during the day, making it unusual to find a completely full stomach.

Changes in fish diet may be determined by seasonal conditions, as different sites and periods have different abiotic conditions and also offer other feeding opportunities (Gandini et al. 2012), creating periods of higher or lower feeding intensity or efficiency. No seasonal differences were observed in stomach fullness, which was correlated with the high occurrence and prevalence of fragments of aquatic insects in the stomach of $A$. tetramerus. This can be explained by the fact that this resource is widely available all year round (Sonoda 2010).

Some studies report that the genus Aequidens may have either omnivorous or malacophagous habits (Ximenes et al. 2011; Montaña and Winemiller 2013). The existence of different trophic guilds probably reflects differences in physical environment and resource availability, as well as morphological variations (Gonçalves et al. 2013; Nogueira and Costa 2014).

According to Agostinho et al. (2007), the omnivorous habits reported for Aequidens sp. are an important strategy in altered environments for increasing energy acquisition according to the availability and quality of food. It has repeatedly been mentioned in the literature that animal items such as aquatic larvae and aquatic and terrestrial adult insects of autochthonous or allochthonous origin are important elements in food chains in streams and an important food source for stream-dwelling fishes (Carvalho et al. 2007; Nogueira and Costa 2014). The food chain in streams seems to depend essentially on items of allochthonous origin, as aquatic insects depend on organic matter from riparian forest (Walker et al. 1991). However, significant differences in the feeding habits of the same species living under different environmental conditions have also been reported (Abelha 2001).

The origin of food resources available to fishes may change substantially along streams and rivers. Shaded headwater forest streams contain mainly allochthonous resources and generally harbor fish species that tend to be omnivorous generalists. However, some autochthonous primary production does exist and is taken advantage of by several fish species. In stream stretches exposed to direct sunlight some species (such as small catfishes, Loricariidae) are the main consumers of periphyton, which they eat as they graze on the surface of submerged tree trunks, macrophytes and rocky substrates (Carvalho et al.
2007). They also consume aquatic invertebrates and detritus. The low occurrence of allochthonous items registered in stomachs during the dry season supports the hypothesis that allochthonous input in tropical ecosystems varies seasonally and is scarce during the dry season (Lowe-McConnell 1999).

Our results confirm those of Rezende and Mazzoni (2005), who found a predominance of autochthonous prey in stretches with a more open canopy predominantly during the dry season. The fact that many species are restricted to areas with vegetation cover has been attributed to the greater amount of allochthonous matter, particularly terrestrial insects, in these areas than in areas without vegetation cover (Mazzoni and Iglesias-Rios 2002). Thus, the high consumption of autochthonous items by $A$. tetramerus may also be related to the reduced vegetation cover in the streamlet analyzed.

Aequidens tetramerus consumes predominantly food of animal origin (Soares 1979). The predominance of autochthonous items of animal origin in the stomachs of individuals from this species observed here is in accordance with the fact that autochthonous prey predominates in environments without vegetation cover (Silva et al. 2014) and the behavioral, morphological and feeding characteristics of genus Aequidens, such as greater activity during the day (Lowe-McConnell 1999), an improved visual system (Soares 1979) and foraging based on exploration of the substrate (Bührnheim 2002). The feeding behavior of $A$. tetramerus facilitates ingestion of autochthonous items, unlike that of other stream-dwelling fish species that swim and feed in midwater, ingesting large amounts of allochthonous items (Mazzoni and Iglesias-Rios 2002).

The high diversity of Cichlidae has been explained by the versatile design of the pharyngeal dentigerous plates used for grinding food (Kullander 2003), as well as the shape and orientation of the mouth, the development of the lips and the capacity for jaw protrusion, reflecting where these fishes capture their food (at the surface, bottom or middle of the water column) (Sampaio and Goulart 2011). This is the case with Crenicichla britskii, which has its mouth in the terminal position and is classified as a generalist insectivore, consuming mainly immature insects in autochthonous material (Casatti 2002). In cichlids, the pharyngeal teeth, which are located behind the oral cavity and are functionally dissociated from the jaws, exhibit major diversification of form and function (Meyer 1993). They are important in the initial stage of the digestive process, and their function is to crush and grind hard prey (Horn 1998), such as aquatic insects that have a chitin exoskeleton (Sampaio and Goulart 2011).

\section{CONCLUSION}

The species $A$. tetramerus has insectivorous feeding habits, and autochthonous insects constitute a large part of its diet, 
possibly because autochthonous animal items are of greater importance in fishes' diets. There was no evidence of seasonal changes in the $\operatorname{diet}$ of $A$. tetramerus except for items consumed less frequently, probably because of the constant availability of food and the broad spectrum of food consumed by this species.

\section{ACKNOWLEDGEMENTS}

We would like to thank the staff at the Ichthyology and Fishing Laboratory, Universidade Federal de Rondônia, particularly Marina Fonseca for helping us with the identification of stomach contents and Carolina Rodrigues da Costa Doria for allowing us to use the facilities.

\section{REFERENCES}

Abelha, M.C.F.; Agostinho, A.A.; Goulart, E. 2001. Plasticidade trófica em peixes de água doce. Acta Scientarium, 23: 425-434.

Abilhoa, V.; Bormaatowski, H.; Otto, G. 2009. Temporal and ontogenetic variations on feeding habits of Hollandichthys multifasciatus (Teleostei: Characidae) in coastal Atlantic rainforest streams, southern Brazil. Neotropical Ichthyology, 7: 415-420.

Agostinho, A.A.; Gomes, L.C.; Pelicice, F.M. 2007. Ecologia e Manejo de Recursos Pesqueiros em Reservatórios do Brasil. 2nd ed. EDUEM, Maringá, 501p.

Angermeier, P.L.; Karr, J.R. 1983. Fish communities along environmental gradients in a system of tropical streams. Envirommental Biology Fishes, 9: 117-135.

Benitez, R.S.; Súarez, Y.R. 2009. Biologia populacional de Serrapinnus notomelas (Eingenmann, 1915) (Characiformes, Cheirodontinae) em um riacho de primeira ordem na bacia do rio Dourados, Alto rio Paraná. Pan-American Journal of Aquatic Sciences, 4: 271-278.

Bührnheim, C.M. 2002. Heterogeneidade de habitat: rasos e fundos em assembléias de peixes de igarapés de terra firme na Amazônia Central. Revista Brasileira de Zoologia, 19: 889-905.

Carvalho, L.N.; Zuanon, J.; Sazima, I. 2007. Natural History of Amazon Fishes. In: Del Claro, K.; Oliveira, P.S.; Rico-Gray, V.; Ramirez, A.; Barbosa, A.A.A.; Bonet, A.; et al (Eds.). Natural history of Amazon fishes. Tropical Biology and Conservation Management: Case studies. v.1. Eolss Publishers, Oxford, England, p. 113-144.

Carvalho, M.S.; Zuanon, J.; Ferreira, E.J.G. 2013. Diving in the sand: the natural history of Pygidianops amphioxus (Siluriformes: Trichomycteridae), a miniature catfish of Central Amazonian streams in Brazil. Environmental Biology of Fishes, 97: 59-68.

Casatti, L. 2002. Alimentação dos peixes em um riacho do parque estadual Morro do Diabo, bacia do alto rio Paraná, sudeste do Brasil. Biota Neotropica, 2: 1-14.

Casatti, L.; Pérez-Mayorga, M.A.; Carvalho, F.R.; Brejāo, G.L.; Costa, I.D. 2013. The stream fish fauna from the rio Machado basin, Rondônia State, Brazil. Check List, 9: 1496-1504.

Espírito-Santo, H.M.V.; Magnusson, W.E.; Zuanon, J.; Mendonça, F.P.; Landeiro, V.L. 2009. Seasonal variation in the composition of fish assemblages in small Amazonian forest streams: evidence for predictable changes. Freshwater Biology, 54: 536-548.
Ferreira, F.S.; Vicentin, W.; Costa, F.E.S.; Súarez, Y.R. 2014. Trophic ecology of two piranha species, Pygocentrus nattereri and Serrasalmus marginatus (Characiformes, Characidae), in the floodplain of the Negro River, Pantanal. Acta Limnologica Brasiliensia, 26: 381-391.

Gandini, C.V.; Boratto, I.A.; Fagundes, D.C.; Pompeu, P.S. 2012. Estudo da alimentação dos peixes no rio Grande à jusante da usina hidrelétrica de Itutinga, Minas Gerais, Brasil. Iheringia, Série Zoologia, 102: 56-61.

Goldstein, R.J. 1973. Cichlids of the World. 1st ed. T.F.H. Publications, Neptune City, 128p.

Gonçalves, A.F.G.; Prudente, B.S.; Carvalho Filho, F.S.; Montag, L.F.A. 2013. Ecologia alimentar de Hemigrammus belottii (Steindachner 1882) (Characiformes: Characidae) em riachos da bacia do Rio Urucu, Amazônia Central, Brasil. Biota Neotropica, 13: 141-147.

Hahn, N.S.; Loureiro, V.E.; Delariva, R.L. 1999. Atividade alimentar de curvina Plagioscion squamosissimus (Heckel, 1840) (Perciformes, Sciaenidae) no rio Paraná. Acta Scitinarium, 21: 309-314.

Hamada, N.; Ferreira-Keppler, R.L. 2012. Guia ilustrado de insetos aquáticos e semiaquáticos da Reserva Florestal Ducke. 1st ed. Universidade Federal do Amazonas, Manaus, 198p.

Hamada, N.; Nessimian, J.L.; Querino, R.B. 2014. Insetos aquáticos na Amazônia brasileira: taxonomia, biologia e ecologia. 1st ed. Embrapa Meio Norte Livros Científicos, Manaus, 724p.

Hammer, Ø.; Harper, D.A.T.; Ryan, P.D. 2001. PAST: Paleontological Statistics Software Package for Education and Data Analysis. Palaeontologia Electronica, 4: 1-9.

Hellawell, J.M.; Abel, R. 1971. A rapid volumetric method for the analysis of the food of fishes. Journal Fish Biology, 3: 29-37.

Horn, M.H. 1998. Feeding and digestion. In: Evans, D.H. (Ed.). The physiology of fishes. v.1. CRC Press, Boca Raton, Florida, p.43-63.

Hyslop, E.J. 1980. Stomach contents analysis: a review of methods and their application. Journal Fish Biology, 100: 411- 429.

Kawakami, E.; Vazzoler, G. 1980. Método gráfico e estimativa de índice alimentar aplicado no estudo de alimentação de peixes. Boletim do Instituto Oceanografico, 29: 205-207.

Krusche, A.V.; Ballester, M.V.R.; Victoria, R.L.; Bernardes, M.C.; Leite, N.KJ.; Hanada, L.; Victoria, D.C.; et al. 2005. Efeitos das mudanças do uso da terra na biogeoquímica dos corpos d'água da bacia do rio Ji-Paraná, Rondônia. Acta Amazonica, 35: 197-205.

Kullander, S.O. 2003. Family Cichlidae (Cichlids). In: Reis, R.E.S.; Kullander, S.O.; Ferraris Jr, C. (Eds.). Check List of the Freshwater Fishes of South and Central America. v.1. EDIPUCRS, Porto Alegre, Rio Grande do Sul, p.605-656.

Lowe-McConnell, R.H. 1999. Estudos ecológicos de comunidades de peixes tropicais. 1st ed. Editora da Universidade de Sáo Paulo, Sáo Paulo, 203p.

Mazzoni, R.; Iglesias, R.R. 2002. Distribution pattern of two fish species in a coastal stream in the southeast of Brazil. Brazilian Journal Biology, 62: 171-178.

Mendonça, F.; Pazin, V.; Espírito-Santo, H.; Zuanon, J.; Magnusson, W.E. 2008. Peixes. In: Oliveira, L.M.; Bacaro, F.B.; Braga-Neto, R.; Magnusson, W.E. (Eds.). Reserva Ducke: A biodiversidade 
amazônica através de uma grade. v.1. Design Editorial, Manaus, Amazonas. p.63-76.

Meyer, A. 1993. Phylogenetic relationships and evolutionary processes in east african cichlid fishes. Trends in Ecology \& Evolution, 8: 279-284.

Montańa, C.G.; Winemiller, K.O. 2013. Evolutionary convergence in Neotropical cichlids and Nearctic centrarchids: evidence from morphology, diet, and stable isotope analysis. Biology Journal Linnaeus Society, 109:1-19.

Moreira, S.S.; Zuanon, J. 2002. Dieta de Retroculus lapidifer (Perciformes: Cichilidae), um peixe reofílico do Rio Araguaia, Estado de Tocantins, Brasil. Acta Amazonica, 32: 691-705.

Nogueira, W.V.; Costa, I.D. 2014. Aspectos da alimentação de Knodus heteresthes (Characiformes, Characidae) no igarapé do Nove, bacia do rio Machado, Rondônia, Brasil. Biotemas, 27: 1-9.

Reis, L.R.G.; Santos, A.C.A. 2014. Dieta de duas espécies de peixes da família Cichlidae (Astronotus ocellatus e Cichla pinima) introduzidos no rio Paraguaçu, Bahia. Biotemas, 27: 83-91.

Rezende, C.F.; Mazzoni, R. 2005. Seasonal variation in the input of allochthonous matter in an Atlantic Rain Forest stream, Ilha Grande-RJ. Acta Limnologica Brasiliensia, 17: 167-175.

Sampaio, A.L.A.; Goulart, E. 2011. Ciclídeos neotropicais: Ecomorfologia trófica. Oecologia Australis, 15: 775-798.

SEDAM, 2010. Boletim Climatológico de Rondônia, 12: 2 - 4 (www. sedam.ro.gov.br). Acesso em 28/12/2014.
Silva, M.R.; Fugi, R.; Carniatto, N.; Ganassin, M.J.M. 2014. Importance of allochthonous resources in the diet of Astyanax aff. fasciatus (Osteichthyes: Characidae) in streams: a longitudinal approach. Biota Neotropica, 14: 1-10.

Soares, M.G.M. 1979. Aspectos ecológicos (alimentação e reprodução) dos peixes do igarapé do Porto, Aripuanã, MT. Acta Amazonica, 9: 325-325.

Sonoda, K.C. 2010. Variaçâo temporal da fauna de insetos aquáticos do córrego Sarandi, DF. 1st ed. Boletim de Pesquisa e Desenvolvimento/Embrapa Cerrados, Brasilia, 73p.

Statsoft, Inc. 2005. Statistica (data analysis software system). Version 7.1. (www.statsoft.com). Acesso em: 12/12/2013.

Walker, I.; Henderson, P.; Sterry, P. 1991. On the patterns of biomass transfer in the benthic fauna of an Amazonian blackwater river, as evidencied by P32 label experiment. Hidrobiologia, 215: 153-162.

Ximenes, L.Q.L.; Mateus, L.A.F.; Penha, J.N.F. 2011. Variação temporal e espacial na composição de guildas alimentares da ictiofauna em lagoas marginais do Rio Cuiabá, Pantanal Norte. Biota Neotropica, 11: 205-215.

Zar J.H. 1999. Biostatistical analysis. 4th ed. Prentice Hall, New Jersey, 663p.

Recebido em 21/01/2015

Aceito em 24/03/2015 